\title{
Physical Abuse and Self-concept of Senior Secondary School Students in Cross-River State, Nigeria
}

\author{
Uchenna E. Ajake, Chinyere C. Ihejiamaizu, Achi N. Oba \\ University of Calabar, Nigeria
}

\begin{abstract}
Survey data collected from 2,000 senior secondary school two (ss2) students in Cross-River State, Nigeria were analysed to determine the influence of child physical abuse on their selfconceptsuch as social self-concept, physical selfconcept, moral self-concept, financial self-concept and family self-concept) were considered in the study. One Way Analysis of Variance was used for data analysis and the hypothesis was tested at 0.05 alpha level. The result obtained showed a significant negative influence of physical abuse on the student's self-concept in terms of the social self, physical self, moral self, family self and financial self-concept respectively.
\end{abstract}

\section{Introduction}

A healthy self-esteem is necessary for the mental well being and a feeling of belonging contributes to a sense of worth. Self concept impacts all aspect of life and realistic view of oneself [2]. This was supported by Sheslow, Taylor and Luken [18] they indicated that a healthy self-concept is a child's amour against the challenges of the world. Children who feel good about themselves seem to have an easier time handling conflict and resisting negative pressures. They tend to smile more readily and enjoy life. Such children are realistic and generally optimistic. In contrast, observation shows that most of the children in our secondary schools, especially Cross-River State have low self-concept, thus challenges can constitute a source of major anxiety and frustration.

Children who think poorly of themselves have a hard time finding solutions to problems. If they are plagued with selfcritical thoughts such as "I'm no good" or "I can't do anything right", they may become passive, withdrawn or depressed [1].

Self-concept encompasses the extent to which individuals feel comfortable with the sense they have of themselves (the self for self) and, to a lesser extent, their accomplishment and how they believe they are viewed by others. It is the sense of contentment and self acceptance that stems from person's appraisal of his (or her) own worth, significance, attractiveness, competence and ability to satisfy aspiration. Sheslow et al. [18] defined selfconcept as the collection of beliefs or feelings that we have about ourselves. It can also be defined as a combination of feelings of being loved. Self-concept is the sum of a number of characteristics an individual exhibits. It is the totality of the perception that one has about one's self, his attitude towards himself it is that of the "self" that is aware of itself, the perception one has of one's characteristics, feeling, attitude, and abilities.

Papalia, Olds and Feldman presented self-concept as the total image of ourselves [17]. It is what we believe about who we are-our total picture of our abilities and traits. It is "a cognitive construction, a system of descriptive and evaluative representation about the self", which determine how we feel about ourselves and guides our actions.

Hence, good parental care usually serves to guarantee the development of healthy self-concept. That is why in all cultures, parents and care givers should give adequate attention, love and care to their offspring or wards [1], [11]. This was supported by the United Nations universal declaration of human right that childhood is entitled to special care and assistance [20]. It also revealed that the child for full and harmonious development of his or her personality should grow up in family environment in an atmosphere of happiness, love and understanding. The paradox of this is that the 21st century world, some parents or caregivers still see relationship with their children as a paradigm of the old concept "spare the rod and spoil the child". Today's childhood still face great danger. Human history is littered with stories of adult brutality and wickedness to children.

These range from beating, whipping, punching, slapping, pushing, kicking, biting, pinching or choking, burning incising, scalding with hot water or object and some inappropriate severe punishment. Reports also abound, on heart breaking stories of children being beaten even to the point of death by family members or caregivers [6].

Physically, child abuse refers to any disciplinary method that leaves a mark on a child. This includes beating, burning, punching, hitting, kicking, shaking or any act or omission that is not an accident but that which brings some injuries to the child's body. In the United States of America (USA) for instance, about $14 \%$ of children are physically abused yearly, and out of those who are abused, an estimated 2000 die whereas others develop low self-concept as a result of the abuse. In fact, 1.1 million cases of physical abuse were reported in that country between 1994 and 1995 and $55 \%$ of the abused were below the age of one year [9]. Physically, a battered child can be permanently deformed due to injuries sustained in the form of cuts, bruises, burns or broken or fractured bones. This in turn lowers their self-esteem. According to Tenevelli, a child who is physically 
abused may likely develop a low self esteem [19]. Also a child who is happy with an achievement but does not feel loved may eventually experience low self esteem. Likewise a child who feels loved but is constantly abused physically and otherwise can also end up with a low self esteem. Thus, healthy selfconcept results when the right balance is attained.

Mansor and Samah in their study used a total of 106 children from five selected protection home and shelter [14]. Analysis on the personality subscales showed that child physical abuse affects the respondents' personality adjustment with mean $71.3 \%$ and $70.8 \%$ simultaneously. Similarly, qualitative on respondents problems in their personality development, with majority of them, showed anxiety (84.2\%), impulsive (73.3\%), aggression (65.3\%) and insecurity (55.5\%) characteristics. This study demonstrated that child physical abuse leave a serious impact on the self concept of the individual which may further influence their future well being.

According to McClowskey and Lichter long term developmental problems such as low self-esteem, depression, physical aggression and school failure are also common [15]. This was supported by Khadijah and Ann [12]. It was also found that physically abused victims often displayed excessive uneasiness, anxiety, low self-esteem, aggression and other negative emotional problems [10]. Children whose care givers are unresponsive, neglectful or use excessive harsh physical punishment are less equipped to accomplish critical developmental task and more likely to develop perceptions of themselves as ineffective and unworthy (Kim \& Cicchetti, [13]; Finkelhor,Ormrod \& Turner, [8]; Finkelhor \&Ormrod, Turner \& Hamby [7]; \& Meyerson; Long; Robert; \& Marx [16]).

Smith [4] carried out a study on the antecedents of self esteem. He administered a 50-item inventory to children in fifth and sixth grade classes. Teachers were asked to rate the children on behaviours presumed to be related on self esteem. He secured two ratings: one subjective and one behavioural. each child's mother was interviewed to receive a background data on parental attitudes and practices. The result showed that the boys who had a high degree of self esteem were active, expressive and successful, both academically and socially.

In discussions, they played active roles, expressed their opinions, did not avoid disagreement, were not upset by criticism, showed little destructiveness and were little troubled by anxiety. Boys in the middle ranges of self esteem, were quite similar to the high self esteem boys, but with conventional value and behaviour patterns they tended to be un-certain in their self rating and were more dependent on social acceptance than were the high esteem boys. The low self-esteem boys tended to be discouraged, depressed and convinced of their inferiority. In social groups they were the listeners; they were easily upset by criticism, self conscious and preoccupied by emotional problems. They were eager for social contact but were unable to secure it. He also found out that the parents of high self esteem children were stricter and less permissive than those with medium or low self esteem. They insisted on high standard of behaviour and were firm and consistent in the enforcement of rules. Their disciplines were not harsh, and were less permissive than other parents in their survey. The parents of low self esteem children tended to be very permissive but inflicted harsh punishments such as beating, punching and flogging when their children gave them trouble. This shows that a child who is constantly abused physically by their parents or care givers will definitely develop low self concept.

Part of being a child is to naturally trust one's parents or caregivers and assume that if the adult says "this is for your own good" it truly is. Hence victims of physical abuse often find it difficult to trust their parents and their own judgement since an integral part of the abuse was reinforcing that they didn't know what was best for them.

Many children and adults who were physically abused early in life simply accept the blame and think that they are the problems and are crazy, bad and worthless. They discredit their own reactions and feelings so that their perceptions match what they think or feel. They often conclude that had they been better, smarter, or more obedient, their parents would have been more loving, supportive, or proud of them. Unfortunately, depression and low self-esteem are natural consequences of this process. Any form of physical abuse is detrimental to the self-concept development of the child. It produces withdrawal syndrome, fearfulness, anxiety, low self-esteem and low self-worth [18], [1]. The purpose of this research was to determine the influence of physical abuse on self-concept of senior secondary school students in Cross-River state- Nigeria.

\section{Methodology}

\subsection{Subjects}

In order to obtain a representative sample, simple and stratified random sampling technique was used in the school and subject selection. Two thousand students were randomly selected from twenty secondary schools in Cross-River state, Nigeria for the study. This includes 1000 males and 1000females respectively. 


\section{Instrumentation}

An instrument captioned Students Opinion Questionnaire (SOQ) was used for the data collection. The research instrument had three sections A-C. Section "A" elicited from the respondents demographic information such as age, sex, school type and class. Section "B" was a five item 4 point likert-type scale that measured the extent of child physical abuse. Section "C" was a 20 item 4 point likert-type scale that measured the respondents self-concept covering social-self, physical-self, moral-self, financial-self and familyself. The investigators visited each of the sample schools having obtained informed consent, assembled the subject selected in the class room and administered the copies of the questionnaires to them. A total of 2000copies of the questionnaire were administered out of which 1973, were properly filled and returned.

\section{Data Analysis}

The data generated were analysed using the One Way Analysis of Variance (ANOVA). Each hypothesis was tested at 0.05 level of significance. In the data analysis, the subjects were categorized into those who were highly, moderately or lowly abused in childhood based on the scores obtained. The One Way Analysis of Variance (ANOVA) was used in testing each hypothesis at 0.05 level significance. Table 1 shows the mean scores and standard deviations of the subjects in various dimensions of self-concept across the level of abuse they experienced.

As shown in Table 2, the results of the data analysis shows that in each situation, the calculated F-value was higher than the critical F-value of 2.99. the results thus show that child abuse influences the individuals self-concept development, including the social, physical, moral as well as financial and family self. The Fisher's Least Significant Difference (LSD) Multiple Comparison Analysis presented in Table 3 shows that in each situation subjects who were highly abused differed significantly from those who were either moderately or lowly abused in their self concept development.

The Table also show that the subjects who were moderately abused also deferred significantly from those who were lowly abused in their self concept development. When the mean scores are considered, it would be seen that in each situation, the subjects who experienced low level abuse in childhood were superior to those who experienced high and moderate levels of physical abuse, while those who experienced moderate level of abuse were superior to their counterparts who experienced high level of abuse. These findings show that physically abused children are inferior to those not abused in selfconcept development.

\section{Results}

The results of analysis of variance showing influence of physical abuse in each of the components of self- concept variables are presented in Tables 1-3. The group mean scores and standard deviations are presented in Table 1, while the ANOVA summary is presented in Table 2. Table 3 shows the Fisher's Least Significant Difference (LSD) Multiple Comparison Analysis. Table 1 shows the mean scores and standard deviations for the three groups of respondents based on their level of physical abuse for each of the self-concept variables. The mean score values reflected one trend; that is the higher the level of physical abuse, the lower the mean of self-concept variables.

The comparison of the three mean values for the three groups for each of the self-concept variables produced F-values of 297.38 for social self-concept, 410.10 for physical self-concept, 224.78 for moral self-concept, 265.33 for financial self concept, 211.46 for family self-concept and 510.95 for overall self-concept (see Table 2). Each of these F- values was greater than the critical f-values of 2.99 at .05 level of significance with 2 and 1970 degrees of freedoms. Hence, the null hypothesis was rejected. This implies that there is a significant influence of physical abuse on each of the five forms of selfconcept and the overall self-concept.

To understand which group mean difference had a significant influence, a port-Hoc Pair-wire Multiple Comparison analysis was carried out on the data using Fishers' Least Significant Difference (LSD) analysis. This is presented in Table 3.

\section{Discussion}

The study revealed that physical abuse has a significant influence on students' self-concept. This implies that students who were more physically abused had low self-concept in terms of their social self, physical self, moral self, financial self and family self respectively. These findings were in line with the previous work of the following (Femi [5]; Papalia, Olds and Feldman [16]; Sheslow et al [18]; Tenevelli [18] Bruce and Meggitt, [2]). Thus, any form of physical abuse is detrimental to the overall development of the child.

From the study of Mansor and Samah [14], Khadijah and Ann [12], Gewirtz and Edleson [10], Kim and Cicccheti [12], Filherhor, Ormod and Turne [6], child physical abuse live a serious impact on the self concept of the individual which may further influence their future well being. 
TABLE 1

Means scores and standard deviations of respondents in self concept across levels of physical abuse

\begin{tabular}{|c|c|c|c|c|c|}
\hline$\underline{\mathrm{S} / \mathrm{N}}$ & Variable & $\mathrm{p}$ (level of abuse) & $\mathrm{N}$ & Mean & SD \\
\hline \multirow[t]{4}{*}{1.} & Social self concept & Low level & 521 & 9.40 & 2.22 \\
\hline & & Moderate level & 764 & 7.06 & 2.18 \\
\hline & & High level & 688 & 6.45 & 2.10 \\
\hline & & Total & 1973 & 7.47 & 2.46 \\
\hline \multirow[t]{4}{*}{2.} & Physical self concept & Low level & 521 & 11.23 & 2.97 \\
\hline & & Moderate level & 764 & 7.83 & 3.01 \\
\hline & & High level & 688 & 6.61 & 2.50 \\
\hline & & Total & 1973 & 8.30 & 3.37 \\
\hline \multirow[t]{4}{*}{3.} & Moral self concept & Low level & 521 & 10.02 & 2.36 \\
\hline & & Moderate level & 764 & 7.79 & 2.45 \\
\hline & & High level & 688 & 7.16 & 2.34 \\
\hline & & Total & 1973 & 8.16 & 2.66 \\
\hline \multirow[t]{4}{*}{4.} & Financial self concept & Low level & 521 & 8.78 & 2.87 \\
\hline & & Moderate level & 764 & 6.37 & 2.46 \\
\hline & & High level & 688 & 5.57 & 2.09 \\
\hline & & Total & 1973 & 6.73 & 2.77 \\
\hline \multirow[t]{4}{*}{5.} & Family self concept & Low level & 521 & 11.20 & 2.20 \\
\hline & & Moderate level & 764 & 9.23 & 2.44 \\
\hline & & High level & 688 & 8.36 & 2.52 \\
\hline & & Total & 1973 & 9.45 & 2.65 \\
\hline \multirow[t]{4}{*}{6.} & Overall self concept & Low level & 521 & 50.62 & 8.66 \\
\hline & & Moderate level & 764 & 38.30 & 9.78 \\
\hline & & High level & 688 & 34.15 & 8.61 \\
\hline & & Total & 1973 & 40.10 & 11.20 \\
\hline
\end{tabular}


TABLE 2

Analysis of variance: influence of physical child abuse on self-concept of senior secondary school students

\begin{tabular}{|c|c|c|c|c|c|}
\hline Variables & Source of Variation & Sum of Squares & $d f$ & Ms & $\mathrm{F}$ \\
\hline \multirow[t]{3}{*}{ Social Self Concept } & Between Groups & 2777.91 & 2 & 1388.95 & $297.38^{*}$ \\
\hline & Within Groups & 9201.23 & 1970 & 4.67 & \\
\hline & Total & 11979.14 & 1972 & & \\
\hline \multirow[t]{3}{*}{ Physical Self Concept } & Between Groups & 6582.78 & 2 & 3291.39 & $410.10^{*}$ \\
\hline & Within Groups & 15810.76 & 1970 & 8.03 & \\
\hline & Total & 22393.54 & 1972 & & \\
\hline \multirow[t]{3}{*}{ Moral Self Concept } & between Groups & 2590.42 & 2 & 1295.21 & $224.78^{*}$ \\
\hline & Within Groups & 11351.56 & 1970 & 5.76 & \\
\hline & Total & 13941.98 & 1972 & & \\
\hline \multirow[t]{3}{*}{ Financial self concept } & Between Groups & 3208.58 & 2 & 1604.29 & $265.33^{*}$ \\
\hline & Within Groups & 11916.0 & 1970 & & \\
\hline & Total & 15124.66 & 1972 & & \\
\hline \multirow[t]{3}{*}{ Family self concept } & Between Groups & 2450.63 & 2 & 1225.31 & $211.46^{*}$ \\
\hline & Within Groups & 11415.51 & 1970 & 5.80 & \\
\hline & Total & 13866.14 & 1972 & & \\
\hline \multirow[t]{3}{*}{ Overall self concept } & Between Groups & 84483.98 & 2 & 42241.99 & $510.95^{*}$ \\
\hline & Within Groups & 162867.72 & 1970 & 82.67 & \\
\hline & Total & 247351.70 & 1972 & & \\
\hline
\end{tabular}

Significant at .05level critical $F_{219 / 0}=; 2.99 ; N=1973$ 


\section{TABLE 3}

Fishers' Least Significant Difference (LSD) Multiple Comparison analysis: influence of physical child abuse and self-concept.

\begin{tabular}{|c|c|c|c|c|}
\hline Variables & Groups (Levels) & Low $(n=521)$ & Moderate $(n=764)$ & High $(n=688)$ \\
\hline \multirow[t]{4}{*}{ Social self Low } & & $9.40^{\mathrm{a}}$ & $2.34^{\mathrm{b}}$ & 2.95 \\
\hline & Moderate & $19.06^{* \mathrm{c}}$ & 7.06 & 0.61 \\
\hline & High & $23.50^{*}$ & $5.37^{*}$ & 6.45 \\
\hline & MSW & 4.67 & & \\
\hline \multirow[t]{4}{*}{ Physical self } & Low & 11.23 & 3.40 & 4.62 \\
\hline & Moderate & $6.68^{*}$ & 7.83 & 1.22 \\
\hline & High & $28.06^{*}$ & $8.19^{*}$ & 6.61 \\
\hline & MSW & 8.03 & & \\
\hline \multirow[t]{4}{*}{ Moral self } & Low & 10.02 & 2.23 & 2.86 \\
\hline & Moderate & 16.35 & 7.79 & 0.63 \\
\hline & High & $20.53^{*}$ & $5.00^{*}$ & 7.16 \\
\hline & MSW & 5.76 & & \\
\hline \multirow[t]{4}{*}{ Financial self } & Low & 8.78 & 2.41 & 3.21 \\
\hline & Moderate & $17.26^{*}$ & 6.37 & 0.80 \\
\hline & High & $22.47^{*}$ & $6.19^{*}$ & 5.57 \\
\hline & MSW & 6.05 & & \\
\hline \multirow[t]{4}{*}{ Family self } & Low & 11.20 & 1.97 & 2.84 \\
\hline & Moderate & $14.41^{*}$ & 9.23 & 0.87 \\
\hline & High & $20.34^{*}$ & $6.86^{*}$ & 8.36 \\
\hline & MSW & 5.80 & & \\
\hline Overall & Low & 50.62 & 12.32 & 16.47 \\
\hline \multirow[t]{3}{*}{ Self concept } & Moderate & $23.84^{*}$ & 38.30 & 4.15 \\
\hline & High & $31.20^{*}$ & $8.69 *$ & 34.15 \\
\hline & MSW & 82.67 & & \\
\hline \multicolumn{5}{|c|}{ a - Group means are placed along the diagonal } \\
\hline \multicolumn{5}{|c|}{ b-Difference between group means is above diagonal } \\
\hline \multicolumn{5}{|c|}{ c - Fishers' t-vales are below the diagonal } \\
\hline${ }^{*}$ - Significant at .0 & el (critical $t=1$ & 1.96) & & \\
\hline
\end{tabular}




\section{Conclusion}

This study shows that physical abuse has a significant influence on each dimension of selfconcept of senior secondary school students. Physically abused children should therefore be empowered which is a helping process and partnership through which individuals and groups are enabled to change situations, and are given skills, resources, opportunities and authority to do so. This will enable them become more self confident in themselves. Also, students who experience high level of child physical abuse should be provided with social support network and psychotherapeutic interventions. Positive self talk can be used $\mathrm{t} o$ change negative inner messages to positive ones. These measures will help them to appreciate their conditions better and become well disposed to prevent further abuse and further damage to their self-concept.

\section{References}

[1] Ajake, U.E., Ukpong E.M., and Jamabo A., (2011). "Sexual Abuse and self-concept among Senior Secondary School Students in Cross-River State, Nigeria." Anals of Modern Education. 3(11) 10-19.

[2] Bruce, T., and Meggit C., (2005). Child care and education (3rd Edition). London: Hodder and Stoughton Educationa.

[3] Burkhardt, M; and Nathaniel, A. (2008). Ethics and issues Clifton Park. New York: Delmar Cenage learning.

[4]Chamberlin, J., (2008). A working definition of empowerment. http:www.power2u.org/articles/empower/ workingdef.html (28th July 2013)

[5] Copper Smith, S., (1968). "Studies in self esteem". Scientist American, 218 (2). 96-106.

[6] Femi, D.A. (2004). "A survey of the prevalence of child abuse and neglect as perceived by parents and guardians" .Journal of the Nigerian Society of Educational Psychologist 3(1) 56-64.

[7] Finkelhor, D., Ormrod, R.K., and Turner, H.A.(2007). "Poly-victimization: A neglected component in child Victimization trauma". Child abuse and Neglect, 31, 7- 26.

[8]Finkelhor, Ormrod, R.K; Turner,H.A; and Hamby, S.L; (2005). "The victimization of children and youth. A Comprehensive national survey". Child maltreatment 10 , 5-25.

[9] Gelles, R.J., and Straus, M.A. (1987). "Is violence towards children increasing: a comparison of 1975 and 1985 national survey rates". Journal of interpersonal violence. 2(1) 212-222.
[10]Gewirtz, A.H; and Edleson, J.L. (2007). "Young children's exposure to intimate partner violence: towards a developmental risks and resilience framework for research and intervention." Journal of family violence. 22. 151-163

[11] Isangedighi, A.J., Ajake, U.E., and Bisong, N.N. (2009). "Child abuse and emotional stability among senior secondary school students in cross-river state, Nigeria". Lawati: A journal of contemporary research 6(1) 17-25

[12]Khadijah, A., and Ann W.S., (2003). Memahami later belakang penderaam kanak-kanak. Pahang: pts publications and distributors Sdn.Bhd.

[13]Kim, J. E., and Cicchetti, D., (2006). "Longitudinal trajectories of self-system process and depressive system processes and depressive system processes and depressive symptoms among maltreated and non-maltreated children". Child Development. 77, 624-639.

[14]Mansor, M., and Samah, A., (2009). "A descriptive analysis of the personality of child physical abuse". International journal of business and social science. 2 (14), 229-240.

[15]McClowskey L.A., and Lichter E.L., (2003). "The contribution of marital violence to adolescent aggression across different relationship". Journal of interpersonal violence-2003: 18 (4), 390-412.

[16]Meyerson, L.A., Long, P.J., Robert, M., and Marx, B.P., (2002). "Influence of childhood sexual abuse, physical abuse, family environment and gender on the psychological adjustment of adolescents". Child Abuse and Neglect 26 (2002) 387-405.

[17]Papalia, D.E., Olds, S. W., \& Feldman R. D., (2004). Human development (9th edition). New York: McGraw Hill.

[18]Sheslow, D., Taylor, C., \& Luken, M. A., (2005). Developing your self-esteem: kids health. New York: Nemours foundations.

[19]Tenevelli, M. J., (2002). Battered child syndrome. Gule Encyclopaedia of Medicine. Javascripts: history.

[20] UNICEF, (2003). A world fit for child: millennium Development Goals special session on child documents. The convention on the rights of the children. New York. UNICEF. P. 109, http://www.uniceforg/publicationwffcenpdf 